\title{
Clinical evaluation of autologous gamma delta $T$ cell-based immunotherapy for metastatic solid tumours
}

\author{
AJ Nicol', , H Tokuyama ${ }^{1,2}$, SR Mattarollo',3, T Hagi', K Suzuki ${ }^{4}, K^{1}$ Yokokawa ${ }^{5}$ and M Nieda' \\ 'Department of Medicine, Centre for Immune and Targeted Therapy, University of Queensland, Brisbane, 4I 20 Australia; ${ }^{2}$ Fourth Department of Internal \\ Medicine, Tokyo Medical University, Tokyo, Japan; ${ }^{3}$ Diamantina Institute for Cancer, Immunology and Metabolic Medicine, University of Queensland, \\ Woolloongabba 4102 Australia; ${ }^{4}$ Department of Hematology, Japanese Red Cross; ${ }^{5}$ Department of Cellular Immunology, Medinet Medical Institute, \\ Setagaya Ku, Tokyo, \\ 1580095 Japan
}

BACKGROUND: Adoptive transfer of ex vivo expanded autologous $\vee \gamma 9 \vee \delta 2 T$ cells may be of therapeutic benefit for cancer because of their potent direct cytotoxicity towards tumour cells, synergistic cytotoxicity when combined with aminobisphosphonates and enhancement of antibody-dependent cell-mediated cytotoxicity.

METHODS: To determine the feasibility and clinical safety of therapy with ex vivo expanded, activated $\vee \gamma 9 \vee \delta 2 T$ cells in combination with zoledronate, we enrolled 18 subjects with advanced solid tumours into a phase I clinical study. Administered indium ${ }^{1 / 1}$-oxinelabelled $\vee \gamma 9 \vee \delta 2 T$ cells were tracked in a cohort of patients.

RESULTS: Administered $\vee \gamma 9 \vee \delta 2 T$ cells had an activated effector memory phenotype, expressed chemokine receptors predictive of homing to peripheral tissues and were cytotoxic in vitro against tumour targets. Adoptively transferred $\vee \gamma 9 \vee \delta 2 T$ cells trafficked predominantly to the lungs, liver and spleen and, in some patients, to metastatic tumour sites outside these organs. No dose-limiting toxicity was observed, but most patients progressed on study therapy. However, three patients administered $\vee \gamma 9 \vee \delta 2 T$ cells while continuing previously ineffective therapy had disease responses, suggesting an additive effect.

CONCLUSION: Therapy with aminobisphosphonate-activated $\vee \gamma 9 \vee \delta 2 T$ cells is feasible and well tolerated, but therapeutic benefits appear only likely when used in combination with other therapies.

British Journal of Cancer (20II) 1 05, 778-786. doi:I0.1038/bjc.20II.293 www.bjcancer.com

Published online 16 August 2011

(c) 20II Cancer Research UK

Keywords: gamma delta $\mathrm{T}$ cells; $\vee \gamma 9 \vee \delta 2 \mathrm{~T}$ cells; immunotherapy; clinical trial

The majority of gamma/delta $(\gamma \delta) \mathrm{T}$ cells in human peripheral blood are of the $\mathrm{V} \gamma 9 \mathrm{~V} \delta 2$ phenotype and constitute $1-5 \%$ of circulating lymphocytes (Carding and Egan, 2002; Chen and Letvin, 2003). Many in vitro and in vivo studies have demonstrated anti-tumour activity of $\mathrm{V} \gamma 9 \mathrm{~V} \delta 2 \mathrm{~T}$ cells, including against renal, prostate, colon and pancreatic cancers and melanoma, myeloma and lymphoma (Kabelitz et al, 2004, 2007; Bonneville and Scotet, 2006; Dieli et al, 2007; Bennouna et al, 2008; Abe et al, 2009). Mechanisms of anti-tumour activity include direct MHC non-restricted killing of tumour cells, antibody-dependent cellmediated cytotoxicity (ADCC) (Lanier et al, 1985; Braakman et al, 1992; Tokuyama et al, 2008) and indirectly through activation of other immune effectors. There is evidence that suggests that $\gamma \delta$ T cell cytotoxicity against a range of tumour cell lines is greater than that achievable with alpha/beta $(\alpha \beta)$ T cells, which have been the focus of most trials of cancer vaccines and adoptive immune therapy (Ensslin and Formby, 1991; Lopez et al, 2000; Guo et al, 2005; Liu et al, 2005).

$\mathrm{V} \gamma 9 \mathrm{~V} \delta 2 \mathrm{~T}$ cells have a unique capacity to recognise and be activated and expanded by non-peptide phosphoantigens,

*Correspondence: Professor AJ Nicol; E-mail: anic9909@bigpond.net.au Received 21 January 20 I I; revised 30 June 20 I ; accepted II July 20 I ; published online 16 August 2011 including aminobisphosphonate drugs, such as zoledronate and pamidronate. Zoledronate has potent activity in activating and expanding $\mathrm{V} \gamma 9 \mathrm{~V} \delta 2 \mathrm{~T}$ cells, especially in combination with IL-2 (Sato et al, 2005; Kondo et al, 2008), and also sensitises tumour cells to $\mathrm{V} \gamma 9 \mathrm{~V} \delta 2 \mathrm{~T}$ cell cytotoxicity in vitro (Gober et al, 2003; Sato et al, 2005; Marten et al, 2007; Mattarollo et al, 2007; Bouet-Toussaint et al, 2008; Todaro et al, 2009) and in vivo in macaque (Gertner-Dardenne et al, 2009), in addition to having potential direct and indirect anti-tumour effects, including apoptotic and anti-proliferative functions (Senaratne et al, 2000; Tassone et al, 2000; Marten et al, 2007). Zoledronate indirectly inhibits MMP-9 and VEGF that are associated with tumour progression and invasion (Santini et al, 2003; Giraudo et al, 2004). This occurs through inhibition of the enzyme farnesyl pyrophosphate (FPP) synthase of the cellular mevalonate pathway, causing accumulation of isoprenoids, such as isopentenyl pyrophosphate (IPP), which stimulates and activates $\gamma \delta \mathrm{T}$ cells (Gober et al, 2003; Green et al, 2004). Of the bisphosphonates tested in vitro, zoledronate is the most potent inhibitor of FPP synthase (Clezardin, 2005; Knight et al, 2005). These properties make zoledronate a particularly interesting candidate for use in therapy aiming to harness the anti-tumour activities of $\gamma \delta \mathrm{T}$ cells (Das et al, 2001; Kato et al, 2001; Gober et al, 2003; Sato et al, 2005; Kondo et al, 2008). 
Adoptive transfer of ex vivo expanded $\gamma \delta$ T cells (Kobayashi et al, 2007; Bennouna et al, 2008; Abe et al, 2009; Noguchi et al, 2011) and in vivo therapeutic manipulation of $\gamma \delta \mathrm{T}$ cells by phosphoantigens and aminobisphosphonates with low-dose IL-2, have been reported and demonstrate potential anti-tumour activities of $\gamma \delta \mathrm{T}$ cells in patients with lymphoid malignancies (Wilhelm et al, 2003) and prostate cancer (Dieli et al, 2007). The combination of intravenous pamidronate or zoledronate and IL-2 for lymphoma, myeloma and prostate cancer was generally well tolerated but with side effects including fever, chills and transient flu-like symptoms (Wilhelm et al, 2003; Dieli et al, 2007) Adoptively transferred ex vivo expanded autologous $\mathrm{V} \gamma 9 \mathrm{~V} \delta 2 \mathrm{~T}$ cells with IL-2 also have limited toxicity, the most frequent adverse event being fever and general fatigue (Kobayashi et al, 2007; Bennouna et al, 2008; Abe et al, 2009). The toxicity of $\mathrm{V} \gamma 9 \mathrm{~V} \delta 2 \mathrm{~T}$ cells expanded with zoledronate and adoptively transferred in combination with a zoledronate infusion is yet to be reported in solid tumour patients.

Although healthy donor $\mathrm{V} \gamma 9 \mathrm{~V} \delta 2 \mathrm{~T}$ cells expand massively when stimulated in vitro by IL-2 in combination with phosphoantigens or bisphosphonates (Wilhelm et al, 2003), the in vitro proliferative capacity of $\mathrm{V} \gamma 9 \mathrm{~V} \delta 2 \mathrm{~T}$ cells from patients with malignancy seems less reproducible. For example, in vitro expansion of $\mathrm{V} \gamma 9 \mathrm{~V} \delta 2$ $\mathrm{T}$ cells was poor in $50 \%$ of lymphoma patients (Wilhelm et al, 2003 ) and in $25 \%$ of renal carcinoma patients (Viey et al, 2005). It is unknown whether this defect in $\mathrm{V} \gamma 9 \mathrm{~V} \delta 2 \mathrm{~T}$ cell proliferation is tumour specific or broadly associated with malignancy, and it is also unknown whether the differences are directly related to differences in $\mathrm{V} \gamma 9 \mathrm{~V} \delta 2 \mathrm{~T}$ cells or due to other cellular constituents in the expansion cultures evaluated.

Adoptive transfer of $\mathrm{V} \gamma 9 \mathrm{~V} \delta 2 \mathrm{~T}$ cells as a therapeutic modality has a number of distinct advantages over active immune therapy with vaccines and direct stimulation of $\mathrm{V} \gamma 9 \mathrm{~V} \delta 2 \mathrm{~T}$ cells in vivo with either pharmaceutical agents or vaccines, but can also be seen as an additional mode of therapy with its own unique set of roles, rather than simply as an alternative to active immune therapy. For example, $\mathrm{V} \gamma 9 \mathrm{~V} \delta 2 \mathrm{~T}$ cells can be adoptively transferred directly after chemotherapy or tumour-targeting monoclonal antibodies, allowing infused cells to provide potential additive or synergistic cytotoxicity timed to coincide with the cytotoxic effects of the pharmaceutical and, in the case of monoclonal antibodies, to provide the potential for enhanced ADCC through $\mathrm{CD} 16 / \mathrm{FcR}$ expression of infused cytotoxic cells (Mattarollo et al, 2007; Tokuyama et al, 2008). In contrast, it is difficult to time the maximal activity of cells expanded with vaccines, and chemotherapy administered after vaccination may inhibit proliferation of the desired cell population. The use of IL-2 to expand $\mathrm{V} \gamma 9 \mathrm{~V} \delta 2 \mathrm{~T}$ cells in vivo has the disadvantage of substantial IL-2 toxicity and the potential for expansion of regulatory $\mathrm{T}$ cells (Tregs), which may inhibit anti-tumour immunity (although both of these latter advantages are negated if IL-2 is used after adoptive therapy of $\mathrm{V} \gamma 9 \mathrm{~V} \delta 2 \mathrm{~T}$ cells).

In order for adoptively transferred $\mathrm{V} \gamma 9 \mathrm{~V} \delta 2 \mathrm{~T}$ cells to have a therapeutic role, they must traffic to tumour sites. Tumourinfiltrating lymphocytes include $\gamma \delta$ T cells in many types of cancer, including colorectal, breast, prostate, ovarian and renal cell carcinomas, suggesting that these cells do have the capacity to infiltrate the tumour environment (Kabelitz et al, 2007). No clinical study has yet addressed the migration pattern of adoptively transferred $\mathrm{V} \gamma 9 \mathrm{~V} \delta 2 \mathrm{~T}$ cells in humans.

In the clinical study described here, the safety and feasibility of adoptive transfer of large numbers of ex vivo expanded autologous $\mathrm{V} \gamma 9 \mathrm{~V} \delta 2 \mathrm{~T}$ cells in combination with zoledronate infusion was investigated in patients with solid tumours. Evaluation of the destination of adoptively transferred $\mathrm{V} \gamma 9 \mathrm{~V} \delta 2 \mathrm{~T}$ cells is also reported. The in vivo effects of zoledronate on $\mathrm{V} \gamma 9 \mathrm{~V} \delta 2 \mathrm{~T}$ cells in peripheral blood were evaluated and localisation of adoptively transferred $\mathrm{V} \gamma 9 \mathrm{~V} \delta 2 \mathrm{~T}$ cells was assessed.

\section{MATERIALS AND METHODS}

\section{Patients and healthy donors}

Patients $(n=18)$ and healthy donors (for in vitro studies only, $n=10$ ) were enrolled after providing informed consent. Patients with malignancy were enrolled for in vitro studies alone $(n=27)$ or for in vitro studies plus therapy with $\mathrm{V} \gamma 9 \mathrm{~V} \delta 2 \mathrm{~T}$ cells and zoledronate $(n=18)$. Patients enrolled had a range of metastatic solid tumours unresponsive to other therapies. Patient characteristics are summarised in Table 1 . The study was approved by the Human Research Ethics Committee of the Greenslopes Private Hospital (Queensland, Australia).

\section{Treatment protocols}

Initially, six patients were treated with a dose-escalation protocol (group A). The planned dose-escalation range of $\mathrm{V} \gamma 9 \mathrm{~V} \delta 2 \mathrm{~T}$ cells was $0.5 \times 10^{7}$ to $500 \times 10^{7}$; however, the maximum dose achieved in this initial group was $280 \times 10^{7}$. Subsequently, nine patients received $\mathrm{V} \gamma 9 \mathrm{~V} \delta 2 \mathrm{~T}$ cells at an approximately fixed dose dependent on the proliferative capacity of their cells (group B). Each dose was generated from $1 / 8$ of a single leukapheresis. Three additional patients received $\mathrm{V} \gamma 9 \mathrm{~V} \delta 2 \mathrm{~T}$ cells while continuing previous therapies that had not induced disease responses, but which were well tolerated (chemotherapy in two cases and hormonal therapy in one case) (group C).

Initial findings from the first three patients in the doseescalation phase of the study indicated that zoledronate pretreatment substantially reduced $\mathrm{V} \gamma 9 \mathrm{~V} \delta 2 \mathrm{~T}$ cell number and expansion capacity. Therefore, the following 15 subjects underwent leukapheresis procedures before zoledronate administration and this initial dose was omitted. The zoledronate dose was split to administer a first dose ( $1 \mathrm{mg}$ per treatment) $24 \mathrm{~h}$ before cell administration and a second $1 \mathrm{mg}$ dose immediately before cell administration. This was based on our in vitro time course studies showing that zoledronate gives rapid but transient tumour sensitisation to $\mathrm{V} \gamma 9 \mathrm{~V} \delta 2 \mathrm{~T}$ cell killing in some cases, but that $24 \mathrm{~h}$ was required before maximal tumour sensitisation develops in other cases (Mattarollo et al, 2007).

\section{Clinical responses}

Computed tomography (CT) scanning was used to evaluate treatment response. Complete remission (CR), partial remission $(\mathrm{PR})$, stable disease (SD) or progressive disease (PD) were determined based on the RECIST criteria (Response Evaluation Criteria In Solid Tumors) (Therasse et al, 2000). During treatment, symptoms, clinical evaluation and haematological and biochemical evaluation of blood were used to monitor adverse events.

\section{Immunological monitoring}

The following monoclonal antibodies for evaluating cell phenotypes using flow cytometry were obtained from Beckman Coulter (Fullerton, CA, USA): CD3 (UCHT1), CD4 (13B8.2), CD8 (SFCI21Thy2D3), CD69 (TP1.55.3), CD56 (N901), CD27 (1A4CD27), CD45RA (2H4LDH11LDB9), CD45 (J.33), TCR-V $\gamma 9$ (IMMU360), TCR-V $\delta 2$ (IMMU389) and TCR-pan $\gamma / \delta$ (IMMU510). Monoclonal chemokine receptor antibodies CCR5 (CTC5), CCR7 (150 503), CXCR3 (49 801) and CXCR5 (51 505.111) were obtained from R\&D Systems Inc. (Minneapolis, MN, USA). Cell number was assessed by addition of flow-count beads (Beckman Coulter), and cell viability was determined by exclusion with 7-AAD (BD Biosciences, San Jose, CA, USA). Cells were stained according to the manufacturers' recommendations. All flow-cytometric analyses were performed using the Coulter Cytomics FC500 five-colour flow cytometer (Beckman Coulter). 
Table I Characteristics of patients, ex vivo expansion of patients' $\vee \gamma 9 \vee \delta 2 T$ cells and treatment and clinical outcomes

\begin{tabular}{|c|c|c|c|c|c|c|c|c|c|c|c|c|c|c|}
\hline \multirow[b]{2}{*}{ Patient } & \multirow[b]{2}{*}{$\begin{array}{c}\text { Age } \\
\text { (years)/ } \\
\text { sex }\end{array}$} & \multirow[b]{2}{*}{$\begin{array}{l}\text { Primary } \\
\text { cancer }\end{array}$} & \multirow[b]{2}{*}{ Metastasis } & \multirow[b]{2}{*}{$\begin{array}{l}\text { Previous } \\
\text { therapy }\end{array}$} & \multirow[b]{2}{*}{$\begin{array}{l}\text { Previous } \\
\text { Zol. } \\
\text { treatment }\end{array}$} & \multicolumn{3}{|c|}{$\% \gamma \delta \mathbf{T}$ in $\mathrm{CD} 3+*$} & \multicolumn{3}{|c|}{ Ex vivo expanded $\gamma \delta \mathbf{T}$} & \multirow[b]{2}{*}{$\begin{array}{l}\text { Toxi- } \\
\text { city }^{\mathbf{a}}\end{array}$} & \multirow[b]{2}{*}{$\begin{array}{c}\text { Clinical } \\
\text { response }\end{array}$} & \multirow[b]{2}{*}{ Comment } \\
\hline & & & & & & $\begin{array}{c}\text { Before } \\
\text { expansion }\end{array}$ & $\begin{array}{c}\text { After } \\
\text { ex vivo } \\
\text { expansion }\end{array}$ & $\begin{array}{l}\text { Expansion } \\
\text { fold }\end{array}$ & $\begin{array}{l}\text { Treat- } \\
\text { ments }\end{array}$ & $\begin{array}{c}\text { Max. dose } / \\
\text { treatment } \\
\left(\times 10^{9} \text { cells }\right)\end{array}$ & $\begin{array}{c}\begin{array}{c}\text { Total } \\
\text { dose }\end{array} \\
\left(\times 10^{9} \text { cells }\right)\end{array}$ & & & \\
\hline \multicolumn{15}{|c|}{ Group A (GDT dose escalation/Zol. treatment) } \\
\hline Al & $58 / F$ & Melanoma & Lung & - & Yes & $0.4(2.0)$ & $8.9(2.8)$ & $28(13)$ & 8 & 0.04 & 0.1 & Yes & PD & \\
\hline $\mathrm{A} 2$ & $59 / M$ & Melanoma & Lung & - & Yes & $2.4(3.0)$ & $23.5(4.0)$ & $8(2)$ & 8 & 0.2 & 0.5 & No & SD & $-^{\mathrm{b}}$ \\
\hline A3 & $66 / F$ & Melanoma & Lung, liver & । & Yes & $0.5(0.7)$ & $20.3(4.8)$ & $95(24)$ & 8 & 0.6 & 2.0 & No & PD & \\
\hline A4 & $60 / F$ & Ovarian cancer & Peritoneum & C & No & $5.7(0.3)$ & $62.3(5.0)$ & $34(7)$ & 8 & 1.5 & 3.5 & No & SD & \\
\hline A5 & $67 / F$ & Melanoma & Abdomen & - & No & $1.3(0.7)$ & $55.7(4.3)$ & $262(81)$ & 8 & 2.3 & 5.0 & No & PD & $-^{c}$ \\
\hline A6 & $56 / F$ & Colon cancer & Lung, liver & C & No & II.I (2.8) & $85.8(4.5)$ & $47(11)$ & 8 & 2.8 & 5.5 & Yes & PD & \\
\hline \multicolumn{15}{|c|}{ Group B (GDT non-dose escalation/Zol. treatment) } \\
\hline $\mathrm{BI}$ & $67 / M$ & Melanoma & $\begin{array}{l}\text { Adrenal } \\
\text { grand, heart }\end{array}$ & । & No & $0.3(0.1)$ & I5.3 (2.2) & $728(111)$ & 6 & 0.3 & 1.0 & No & SD & \\
\hline B2 & $48 / \mathrm{F}$ & $\begin{array}{l}\text { Adeno- } \\
\text { carcinoma }\end{array}$ & Bone & $\mathrm{R}$ & No & $2.1(0.5)$ & $53.6(9.9)$ & $144(72)$ & 8 & 0.5 & 1.1 & Yes & PD & \\
\hline B3 & $47 / M$ & $\begin{array}{l}\text { Cholangio- } \\
\text { carcinoma }\end{array}$ & $\begin{array}{l}\text { Local } \\
\text { advanced } \\
\text { disease }\end{array}$ & C & No & $1.8(0.1)$ & $59.5(4.8)$ & $17(2)$ & 8 & 0.4 & 1.4 & No & PD & \\
\hline B4 & $65 / F$ & Melanoma & $\begin{array}{l}\text { Lung, } \\
\text { abdominal } \\
\text { mass }\end{array}$ & । & No & $0.5(0.1)$ & $12.3(1.9)$ & 159 (84) & 8 & 0.5 & 1.4 & No & NE & \\
\hline B5 & $61 / F$ & Melanoma & Lung & - & No & $0.8(0.0)$ & $71.4(6.6)$ & $586(273)$ & 7 & 1.0 & 1.7 & No & PD & \\
\hline B6 & $61 / F$ & Ovarian carcinoma & Peritoneum & C & No & $5.1(0.7)$ & $86.6(2.0)$ & $43(7)$ & 8 & 1.0 & 3.0 & No & PD & \\
\hline B7 & $5 \mathrm{I} / \mathrm{F}$ & Colon cancer & Lung, liver & $C, R, I$ & No & $2.6(0.3)$ & $70.0(3.8)$ & $86(14)$ & 8 & 0.8 & 3.3 & Yes & PD & \\
\hline B8 & $57 / F$ & Colon cancer & Lung & C, R & Yes & $2.3(0.1)$ & $64.0(3.1)$ & $253(25)$ & 6 & 1.5 & 4.6 & No & PD & \\
\hline B9 & $68 / M$ & Duodenal cancer & $\begin{array}{l}\text { Lung, } \\
\text { abdomen }\end{array}$ & C & No & $9.1(0.4)$ & $71.7(3.9)$ & $78(13)$ & 8 & 2.2 & 7.2 & Yes & PD & \\
\hline \multicolumn{15}{|c|}{ Group C (GDT/Zol. treatment with other therapy) } \\
\hline $\mathrm{Cl}$ & $58 / \mathrm{F}$ & Breast cancer & $\begin{array}{l}\text { Brain, liver, } \\
\text { lung }\end{array}$ & C & Yes & $1.3(0.1)$ & $22.4(4.5)$ & 119 (34) & 7 & 0.3 & 0.9 & No & PR & $-^{d}$ \\
\hline $\mathrm{C} 2$ & $44 / F$ & Breast cancer & Bone, liver & $C, R, H$ & Yes & I.I (0.1) & $24.3(5.7)$ & $269(143)$ & 7 & 1.5 & 3.6 & Yes & $C R$ & - $^{\mathrm{e}}$ \\
\hline $\mathrm{C} 3$ & $33 / F$ & Cervical cancer & Lung, pelvis & C & No & $2.3(1.0)$ & $78.9(6.9)$ & 160 (32) & 8 & 1.9 & 4.0 & Yes & PR & $-^{d}$ \\
\hline
\end{tabular}

Abbreviations: $C=$ chemotherapy; $C R=$ complete remission; $\gamma \delta \mathrm{T}=\mathrm{V} \gamma \mathrm{V} \delta 2 \mathrm{~T}$ cell; $\mathrm{H}=$ hormonal therapy; I=immunotherapy; inj. $=$ injection; $N E=$ not evaluable; $\mathrm{PD}=$ progressive disease; $\mathrm{PR}=$ partial remission; $\mathrm{R}=$ radiotherapy; $\mathrm{S}=$ surgery; $\mathrm{SD}=$ stable disease; Zol =Zoledronate; $*$ Represents the mean (s.e.) from $6-8$ vaccines. ${ }^{a}$ Fever after infusion, Al also had vomiting. ' Large bulk of disease but stable. ${ }^{c}$ No new lesions. 'With chemotherapy. "With hormonal therapy.

\section{Proliferation and preparation of $\mathrm{V} \gamma 9 \mathrm{~V} \delta 2 \mathrm{~T}$ cells}

Cells for adoptive transfer were generated under good manufacturing practice (GMP) conditions in purpose-built GMP laboratories within the University of Queensland laboratories at the Greenslopes Private Hospital. Peripheral blood mononuclear cells (PBMCs) were isolated by density gradient centrifugation using Ficoll-Paque (GE Healthcare, Buckinghamshire, UK) and $\mathrm{V} \gamma 9 \mathrm{~V} \delta 2$ $\mathrm{T}$ cells selectively proliferated by culture of PBMCs in RPMI 1640 media (Lonza, Walkersville, MD, USA) supplemented with $10 \%$ human $\mathrm{AB}$ plasma (Lonza), L-glutamine (2 mM; Lonza) and gentamycin ( $40 \mu \mathrm{g}$; Pfizer, Bentley, WA, Australia). Recombinant human IL-2 (700 $\mathrm{IU} \mathrm{ml}^{-1}$; Novartis, Basel, Switzerland) and zoledronate $(1 \mu \mathrm{m}$; Novartis) were added on day 0 and additional IL-2 $\left(350 \mathrm{IU} \mathrm{ml}^{-1}\right)$ was added every $2-3$ days during the culture period. After 7-14 days culture, purified effector cell populations containing 70-95\% $\mathrm{V} \gamma 9 \mathrm{~V} \delta 2 \mathrm{~T}$ cells were obtained for in vitro functional assessment by depletion of $\mathrm{CD} 4^{+}, \mathrm{CD} 8^{+}$and $\mathrm{CD} 56^{+}$ cells using miniMACS (Miltenyi Biotec, Bergisch Gladbach, Germany). Cell populations for adoptive transfer were not purified, but were enriched by the culture procedure. The percentage of adoptively transferred cells that were $\mathrm{V} \gamma 9 \mathrm{~V} \delta 2 \mathrm{~T}$ cells is shown in Table 1.

\section{In vitro cytotoxicity assessment of $\mathrm{V} \gamma 9 \mathrm{~V} \delta 2 \mathrm{~T}$ cells}

Cancer cell lines HT-29 and DLD-1 (colorectal), NCI-H358 (lung), TSU-Pr1 (bladder), DU-145 (prostate) and MDA-MB231 (breast) were used as representative solid tumour targets for functional assessment of $\mathrm{V} \gamma 9 \mathrm{~V} \delta 2 \mathrm{~T}$ cells. These cells were obtained from the American Type Culture Collection (ATCC; Manassas, VA, USA). All cell lines were cultured in RPMI 1640 media supplemented with $10 \%$ FCS, L-glutamine and gentamycin and maintained at $37^{\circ} \mathrm{C}$ in $5 \% \mathrm{CO}_{2}$. Adherent cells were detached using $0.05 \mathrm{~m}$ EDTA.

The cytotoxicity of $\mathrm{V} \gamma 9 \mathrm{~V} \delta 2 \mathrm{~T}$ cells against tumour targets was determined using the tetrazolium-based (MTS) assay referred to as CellTiter 96 (Promega, Madison, WI, USA) as described previously (Mattarollo et al, 2007). Purified $\mathrm{V} \gamma 9 \mathrm{~V} \delta 2 \mathrm{~T}$ cells were co-cultured with tumour targets at an effector/target ratio of $5: 1$ for a $4 \mathrm{~h}$ period at $37^{\circ} \mathrm{C}$. After co-culture, non-adherent effector cells and non-viable targets were removed and replaced with the MTS tetrazolium salt. After $4 \mathrm{~h}$ incubation, optical density values were read directly at $492 \mathrm{~nm}$ using the Multiskan Ascent microplate reader (Thermo, Vantaa, Finland). The viability of target cells was calculated as a percentage of the non-treated target control.

\section{Radiolabelling and clinical gamma $(\gamma)$ camera imaging of $\mathrm{V} \gamma 9 \mathrm{~V} \delta 2 \mathrm{~T}$ cell distribution}

Using radioactive indium ${ }^{111}$ oxine $\left(\mathrm{In}^{111}\right)$-labelled autologous $\mathrm{V} \gamma 9 \mathrm{~V} \delta 2 \mathrm{~T}$ cells, the migration of infused ex vivo expanded $\mathrm{V} \gamma 9 \mathrm{~V} \delta 2$ $\mathrm{T}$ cells was evaluated in three patients (A2, B1 and B7). $\mathrm{V} \gamma 9 \mathrm{~V} \delta 2 \mathrm{~T}$ cells $\left(1 \times 10^{8}\right)$ harvested from in vitro culture were labelled by incubation with $20 \mathrm{MBq}$ of commercially prepared $\operatorname{In}^{111}$ (GE Healthcare) for $15 \mathrm{~min}$, followed by two washes to remove any residual $\mathrm{In}^{111}$. Labelled cells were resuspended in saline and the radioactivity of the patient dose recorded (Atomlab 300 dose calibrator, Biodex, Shirley, NY, USA) and was in the range of $12-$ 

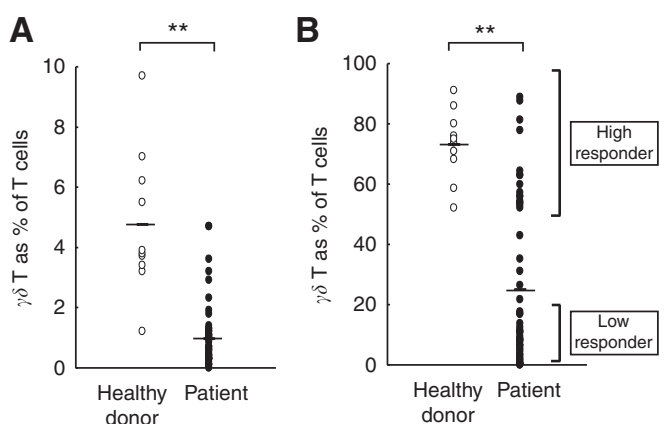

E

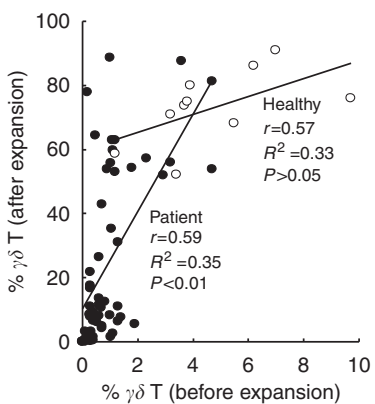

C

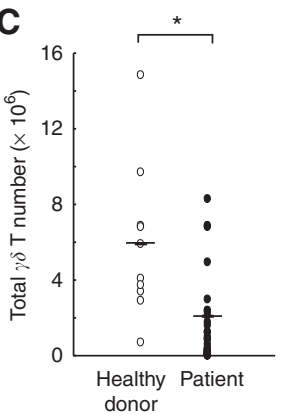

D

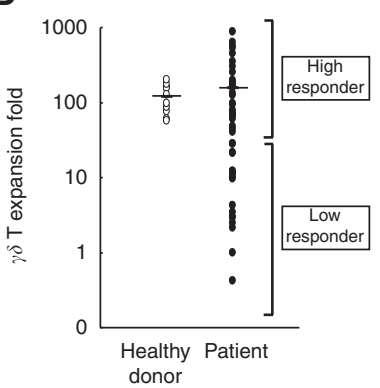

G $100 \square$ Healthy donor

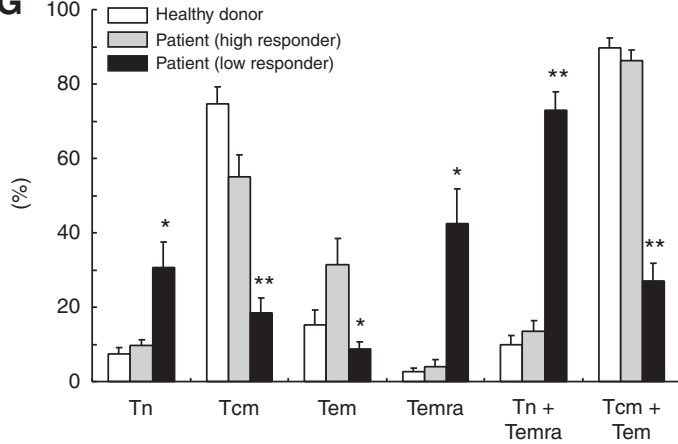

Figure I Proliferation and memory profiles of $\vee \gamma 9 \vee \delta 2 T$ cells cultured in vitro with zoledronate and IL-2 for 14 days $(n=10$ healthy donors and $n=45$ patients with solid tumours). (A and $\mathbf{B}$ ) The percentage of $\vee \gamma 9 \vee \delta 2 \mathrm{~T}$ cells from peripheral blood of healthy donors and patients before and after in vitro culture. (C and $\mathbf{D}) \vee \gamma 9 \vee \delta 2 \mathrm{~T}$ cell numbers generated from $\mathrm{I} \times 10^{6}$ healthy donor and patient PBMCs cultured in vitro and the expansion capacity. (E and $\mathbf{F}$ ) Correlation between pre-culture $\vee \gamma 9 \vee \delta 2 T$ cell percentages and post-culture $\vee \gamma 9 \vee \delta 2$ T cell percentages, expansion fold and absolute cell numbers. Hollow dots = healthy donors; solid dots = patients. $(\mathbf{G})$ Naive $(T \mathrm{n})$, central memory $(T \mathrm{~cm})$, effector memory $(T e m)$ and $C^{2} 45 R A^{+}$effector memory $(T e m r a)$ $\vee \gamma 9 \vee \delta 2 T$ cell memory subset profiles of pre-cultured healthy donor PBMCs $(n=5)$ compared with low $(n=10)$ and high $(n=10)$ responding patient PBMCs (mean + s.e.m., $* * * 0.01$, $* P<0.05)(\gamma \delta T=\vee \gamma 9 \vee \delta 2 T$ cells $)$.

$17 \mathrm{MBq}$. Patients received an infusion of $5 \times 10^{7}$-labelled $\mathrm{V} \gamma 9 \mathrm{~V} \delta 2 \mathrm{~T}$ cells through a peripheral intravenous (IV) line. Full-body $\gamma$ imaging was performed using a dual-headed $\gamma$-camera (20\% energy windows $\sim 173$ and $247 \mathrm{keV}$ ) to monitor the location of labelled $\mathrm{V} \gamma 9 \mathrm{~V} \delta 2 \mathrm{~T}$ cells serially for $48 \mathrm{~h}$ starting within $30 \mathrm{~min}$ of injection $(t=0 \mathrm{~h})$ and then at $1,4,8,24$ and $48 \mathrm{~h}$ after injection. Cell accumulation in different organs was scored on a scale from 0 to 4 : $0=$ no accumulation, $1=$ minimal accumulation, $2=$ low accumulation, $3=$ medium accumulation and $4=$ large accumulation.

\section{Statistical analysis}

All statistical analyses were performed using Student's $t$-test and results were considered significant if $P<0.05$.

\section{RESULTS}

\section{Phenotype and cytotoxic activity of in vitro expanded $\mathrm{V} \gamma 9 \mathrm{~V} \delta 2 \mathrm{~T}$ cells}

The characteristics of $\mathrm{V} \gamma 9 \mathrm{~V} \delta 2 \mathrm{~T}$ cells in peripheral blood and after in vitro expansion for healthy donors $(n=10)$ and patients with active, metastatic cancer $(n=45)$ are summarised in Figure 1. Additional details for the subset of cancer patients $(n=18)$ involved in the treatment phase of this study are summarised in Table 1.

In comparison with healthy donors, patients with active cancer, as a group, had significantly lower $\mathrm{V} \gamma 9 \mathrm{~V} \delta 2 \mathrm{~T}$ cells as a percentage of T cells $(P<0.01$; Figure $1 \mathrm{~A})$, lower percentages of $\mathrm{V} \gamma 9 \mathrm{~V} \delta 2 \mathrm{~T}$ cells in a potential therapeutic product after culture $(P<0.01$; Figure 1B) and lower numbers of $\mathrm{V} \gamma 9 \mathrm{~V} \delta 2 \mathrm{~T}$ cells that could be generated from a starting point of $1 \times 10^{6}$ PBMCs $(P<0.05$; Figure 1C). Although the expansion capacity of $\mathrm{V} \gamma 9 \mathrm{~V} \delta 2 \mathrm{~T}$ cells was similar for cancer patients as a group compared with healthy individuals (Figure 1D), the cancer patient population was highly variable with respect to the expansion potential of $\mathrm{V} \gamma 9 \mathrm{~V} \delta 2 \mathrm{~T}$ cell numbers, and this is reflected in substantial variation in the purity of the potential $\mathrm{V} \gamma 9 \mathrm{~V} \delta 2 \mathrm{~T}$ cell therapeutic product (Figure 1B) and the total number of $\mathrm{V} \gamma 9 \mathrm{~V} \delta 2 \mathrm{~T}$ cells that could be generated (Figure 1C). The percentage of $\mathrm{T}$ cells that were $\mathrm{V} \gamma 9 \mathrm{~V} \delta 2 \mathrm{~T}$ cells before expansion culture predicted for both the purity of the final product (Figure 1E) and the total number of $\mathrm{V} \gamma 9 \mathrm{~V} \delta 2 \mathrm{~T}$ cells that could be generated (Figure $1 \mathrm{~F}$ ). The relative number of $\mathrm{V} \gamma 9 \mathrm{~V} \delta 2$ $\mathrm{T}$ cells from different subsets before culture was predictive for $\mathrm{V} \gamma 9 \mathrm{~V} \delta 2 \mathrm{~T}$ cell expansion capacity, with high numbers of $\mathrm{Tn}+$ Temra predicting for poor expansion (Figure 1G) and the patient subgroups, defined as high and low responders, as shown in Figure $1 \mathrm{~B}$ and $\mathrm{D}$, differing with respect to their $\mathrm{V} \gamma 9 \mathrm{~V} \delta 2 \mathrm{~T}$ cell subset profile.

Patient clinical factors found to predict for the capacity to generate large numbers of $\mathrm{V} \gamma 9 \mathrm{~V} \delta 2 \mathrm{~T}$ cells included whether there had been previous treatment with zoledronate (Figure 2A) and tumour type (melanoma $v s$ non-melanoma, Figure $2 \mathrm{~B}$ ). Patients who had received zoledronate at any time before collection of blood samples had lower initial $\mathrm{V} \gamma 9 \mathrm{~V} \delta 2 \mathrm{~T}$ cell numbers, less $\mathrm{V} \gamma 9 \mathrm{~V} \delta 2 \mathrm{~T}$ cells as a fraction of all lymphocytes, lower proliferative potential and a lower final number of $\mathrm{V} \gamma 9 \mathrm{~V} \delta 2 \mathrm{~T}$ cells achievable (Figure 2A). As a group, patients with melanoma had lower initial $\mathrm{V} \gamma 9 \mathrm{~V} \delta 2 \mathrm{~T}$ cells and lower final numbers of $\mathrm{V} \gamma 9 \mathrm{~V} \delta 2 \mathrm{~T}$ cells generated, despite no patients having been exposed to zoledronate (Figure 2B). The lack of exposure to zoledronate may explain the greater proliferative capacity of melanoma patients, as a group, than patients with other malignancies of whom many had received zoledronate.

Our method of in vitro culture generated $\mathrm{V} \gamma 9 \mathrm{~V} \delta 2 \mathrm{~T}$ cells with purity of up to $90 \%$ after 14 days (without an additional purification step, Figure 1B and 3A). CD69 expression on $\mathrm{V} \gamma 9 \mathrm{~V} \delta 2$ $\mathrm{T}$ cells increased significantly after in vitro expansion, indicating an activated phenotype (Figure 3B). The majority of the expanded 

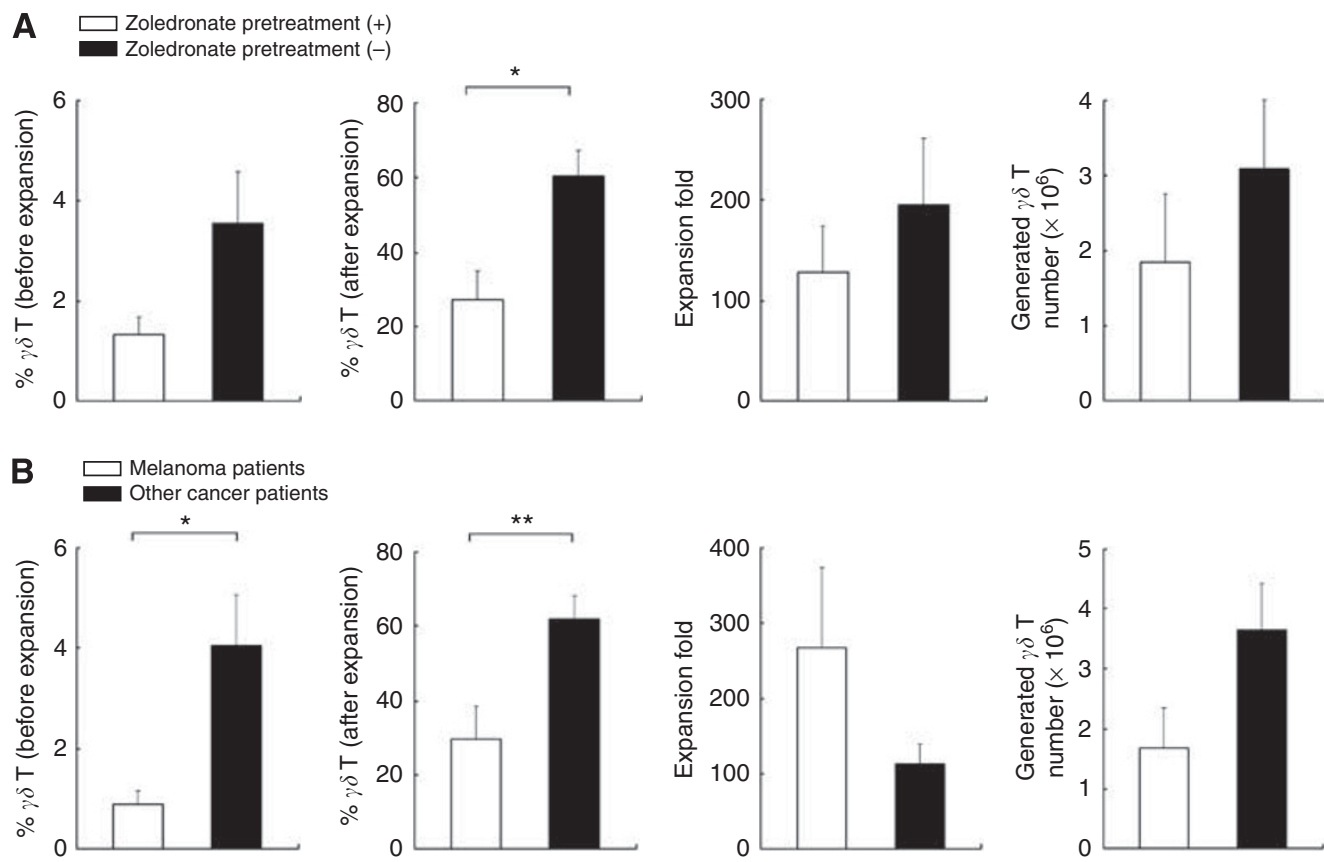

Figure 2 Proliferation of $\vee \gamma 9 \vee \delta 2$ T cells cultured in vitro with zoledronate and IL-2 for I 4 days. Results of total cell numbers obtained are derived from a fixed starting number of PBMCs. (A) Previous treatment with zoledronate $(n=6)$ vs no previous treatment with zoledronate $(n=12)$. (B) Melanoma patients $(n=7)$ vs other cancer patients $(n=1 \mathrm{I})($ mean + s.e.m., $* * * 0.0 \mathrm{I}, * P<0.05)(\gamma \delta T=\vee \gamma 9 \vee \delta 2 T$ cells).

A
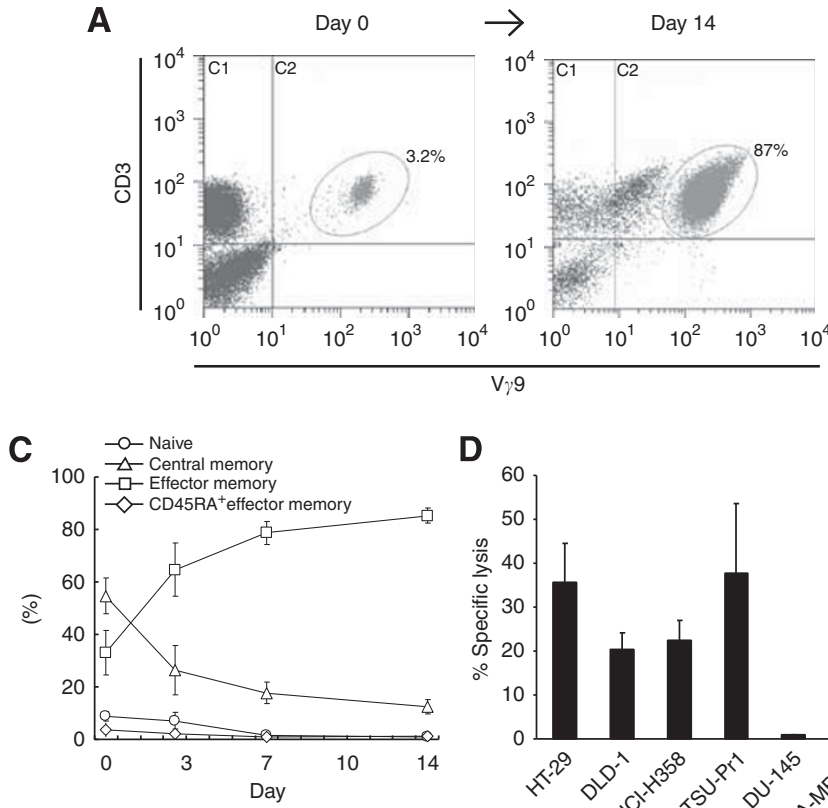

D

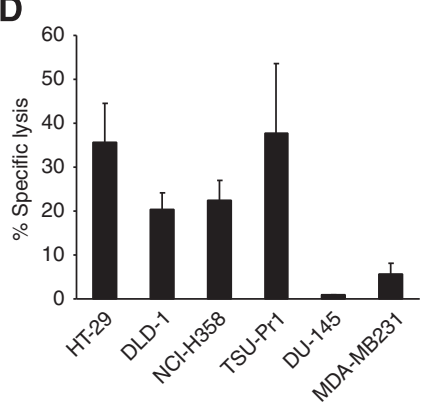

B

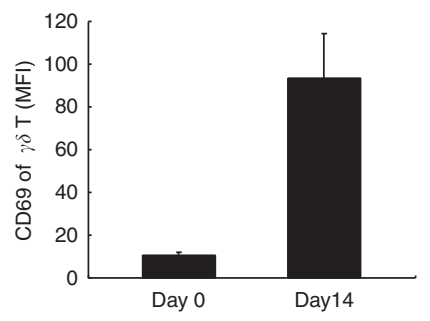

E

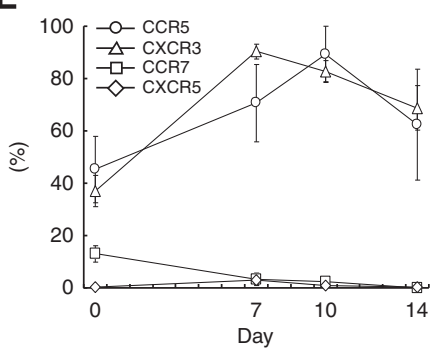

Figure 3 Phenotype and functional activity of ex vivo expanded patient $\vee \gamma 9 \vee \delta 2 T$ cells. (A) Representative flow cytometry dot plot showing selective expansion of $\vee \gamma 9 \mathrm{~V} \delta 2 \mathrm{~T}$ cells after 14 days culture in zoledronate and IL-2. (B) CD69 expression on $\vee \gamma 9 \vee \delta 2 \mathrm{~T}$ cells (MFI value) after in vitro culture (mean \pm s.e.m.; $n=10$ ). (C) Relative proportions of $\vee \gamma 9 \vee \delta 2 T$ cell subsets during the in vitro culture period (mean \pm s.e.m.; $n=7$ ). (D) Cytotoxicity of expanded $\vee \gamma 9 \vee \delta 2 T$ cells against various solid tumour cell lines (mean \pm s.e.m.). Means are derived from separate killing assays using $\vee \gamma 9 \vee \delta 2 T$ cells from 3 to 5 subjects. (E) Chemokine receptor profiles (peripheral-homing CCR5 and CXCR3; lymph node-homing CCR7 and CXCR5) of $\vee \gamma 9 \vee \delta 2 T$ cells during in vitro culture (mean \pm s.e.m.; $n=4)(\gamma \delta T=\vee \gamma 9 \vee \delta 2 T$ cells).

$\mathrm{V} \gamma 9 \mathrm{~V} \delta 2 \mathrm{~T}$ cell population from normal donors and patients in the high-responder group were of the effector memory (Tem) and of the central memory $(\mathrm{Tcm})$ phenotype (Figure $3 \mathrm{C})$. Correlating with the effector phenotype observed using surface marker analysis, cultured $\mathrm{V} \gamma 9 \mathrm{~V} \delta 2 \mathrm{~T}$ cells were cytotoxic against a range of solid tumour cell lines in vitro, including HT29, DLD-1, NCI-H358 and TSU-Pr1 (Figure 3D). In vitro expanded $\mathrm{V} \gamma 9 \mathrm{~V} \delta 2 \mathrm{~T}$ cells had upregulated expression of peripheral tissue-homing chemokine receptors, CCR5 and CXCR3. In contrast, expression of lymphoidhoming receptors, CCR7 and CXCR5, decreased to undetectable levels (Figure 3E). These results show that $\mathrm{V} \gamma 9 \mathrm{~V} \delta 2 \mathrm{~T}$ cells expanded in vitro from cancer patients have effector cell characteristics including the capacity to effectively kill tumour targets and chemokine receptor expression profiles, suggesting the 
potential to migrate to peripheral tumour sites, although potentially not to disease-involved lymph nodes.

The population of cells infused to patients was predominantly $\mathrm{V} \gamma 9 \mathrm{~V} \delta 2 \mathrm{~T}$ cells as shown in Table 1 . The other cells infused (expressed as a mean, s.d. and range) included NK cells (18 $\pm 22 \%$, range $0.5-75 \%) \mathrm{CD}^{+} \mathrm{T}$ cells $(6 \pm 6 \%$, range $0.5-24 \%)$ and $\mathrm{CD} 8^{+}$ $\mathrm{T}$ cells $(17 \pm 16 \%$, range $2-64 \%)$. We did not directly evaluate for co-expression of the $\mathrm{V} \gamma 9 \mathrm{~V} \delta 2 \mathrm{~T}$ cell receptor and CD56 (as separate analysis tubes were used), but $\mathrm{V} \gamma 9 \mathrm{~V} \delta 2 \mathrm{~T}$ cells are distinguishable in the context of these cultured cells from most $\alpha \beta \mathrm{T}$ cells (either $\mathrm{CD}^{+}{ }^{+}$or $\mathrm{CD} 8^{+}$) as they are CD3 positive but double negative for CD4 and CD8. The majority of cells administered were both $\mathrm{V} \gamma 9 \mathrm{~V} \delta 2$ TCR positive and CD4CD8 double negative. With these caveats, our results indicate that a substantial proportion (about half) of the administered $\mathrm{V} \gamma 9 \mathrm{~V} \delta 2 \mathrm{~T}$ cells are $\mathrm{CD}^{2} 6^{+}(49 \pm 23 \%$, mean \pm s.d., range $27-73 \%$ ).

\section{Clinical outcomes of $\mathrm{V} \gamma 9 \mathrm{~V} \delta 2 \mathrm{~T}$ cell administration}

Details of administered $\mathrm{V} \gamma 9 \mathrm{~V} \delta 2 \mathrm{~T}$ cells, including cell numbers, purity, possible treatment-related adverse effects and clinical outcomes are summarised in Table 1. For preliminary assessment of safety and maximal tolerated doses of intravenous infusion of in vitro expanded $\mathrm{V} \gamma 9 \mathrm{~V} \delta 2 \mathrm{~T}$ cells, six patients (four melanoma, one ovarian cancer, one colon cancer) were treated with escalating doses of $\mathrm{V} \gamma 9 \mathrm{~V} \delta 2 \mathrm{~T}$ cells. In this group, the maximum $\mathrm{V} \gamma 9 \mathrm{~V} \delta 2$ $\mathrm{T}$ cell dose per injection ranged from $0.04 \times 10^{9}$ to $2.8 \times 10^{9}$. The total accumulated dose of $\mathrm{V} \gamma 9 \mathrm{~V} \delta 2 \mathrm{~T}$ cells over the treatment period ranged from $0.1 \times 10^{9}$ to $5.5 \times 10^{9}$ with a mean of $2.8 \times 10^{9}$. Maximal single dose and total dose were much lower than those predicted from the preclinical evaluation (before zoledronate administration) in the first three subjects because of markedly reduced expansion of $\mathrm{V} \gamma 9 \mathrm{~V} \delta 2 \mathrm{~T}$ cells from harvests undertaken after zoledronate administration.

The maximum dose of $\mathrm{V} \gamma 9 \mathrm{~V} \delta 2 \mathrm{~T}$ cells per treatment in the subsequent non-dose-escalation protocol $(n=12)$ ranged from $0.3 \times 10^{9}$ to $2.2 \times 10^{9}$. The total doses of $\mathrm{V} \gamma 9 \mathrm{~V} \delta 2 \mathrm{~T}$ cells administered ranged from $1.0 \times 10^{9}$ to $7.2 \times 10^{9}$ with a mean of $2.8 \times 10^{9}$, from a total of 6-8 treatments. Three patients (two breast cancer and one cervical) were treated with concurrent use of other therapy (two with chemotherapy and one with hormone therapy).

Of the 18 patients treated, 7 had fevers above $38^{\circ} \mathrm{C}$ believed to be related to study therapy. Overall, side effects were manageable, tolerated by patients, did not interfere with their treatment and resolved within $24 \mathrm{~h}$.

\section{Treatment outcome}

Clinical response to treatment is summarised in Table 1 . In the group of 15 patients with advanced cancer treated only with $\mathrm{V} \gamma 9 \mathrm{~V} \delta 2 \mathrm{~T}$ cells plus zoledronate, 3 had SD while 12 patients had $\mathrm{PD}$ during the study period. Although difficult to assess with their generally poor outcomes, there seemed no correlation between maximum or total dose of $\mathrm{V} \gamma 9 \mathrm{~V} \delta 2 \mathrm{~T}$ cells and clinical outcome. For example, patient A2 had large bulky disease, progressing before enrolment, but was stable during treatment and for a prolonged period after therapy was completed.

Three additional patients were assessed for treatment outcomes although their $\mathrm{V} \gamma 9 \mathrm{~V} \delta 2 \mathrm{~T}$ cells were administered in parallel with other therapies. All three of these patients experienced at least a partial response and one (breast cancer) had a complete response. Although it is not possible to know whether $\mathrm{V} \gamma 9 \mathrm{~V} \delta 2$ $\mathrm{T}$ cells contributed to these responses, inclusion criteria dictated that subjects enrolled in our study were considered unlikely to respond to standard therapy. For example, patient $\mathrm{C} 2$ with breast cancer was non-responsive to hormonal therapy alone but had CR when hormonal therapy was combined with $\mathrm{V} \gamma 9 \mathrm{~V} \delta 2 \mathrm{~T}$ cell/ zoledronate infusions. Patient $\mathrm{C} 1$ had $\mathrm{PD}$ when treated with chemotherapy alone before enrolment but had a PR and substantial symptomatic improvement when $\mathrm{V} \gamma 9 \mathrm{~V} \delta 2 \mathrm{~T}$ cell/ zoledronate infusions were added to the same chemotherapy protocol. Patient C3, who presented with a rapid and florid relapse soon after cessation of previous chemotherapy, had a partial response to the combination of further chemotherapy and $\mathrm{V} \gamma 9 \mathrm{~V} \delta 2$ $\mathrm{T}$ cell/zoledronate infusions.

\section{In vivo distribution and tumour localisation of adoptively transferred $\mathrm{V} \gamma \mathbf{9} \mathrm{V} \delta 2 \mathrm{~T}$ cells}

To establish the migratory pattern of $\mathrm{V} \gamma 9 \mathrm{~V} \delta 2 \mathrm{~T}$ cells in vivo, trafficking of in vitro expanded $\mathrm{V} \gamma 9 \mathrm{~V} \delta 2 \mathrm{~T}$ cells was investigated in a cohort of patients $(n=3)$.

In all patients administered $\mathrm{In}^{111}$-labelled $\mathrm{V} \gamma 9 \mathrm{~V} \delta 2 \mathrm{~T}$ cells (patients $\mathrm{A} 2, \mathrm{~B} 1, \mathrm{~B} 7,5 \times 10^{7} \mathrm{~V} \gamma 9 \mathrm{~V} \delta 2 \mathrm{~T}$ cells per dose), rapid migration to the lungs occurred, where cells remained for $4-7 \mathrm{~h}$. During this period, cell numbers (according to $\gamma$-activity) in the lungs then slowly decreased with gradual migration into the liver and spleen. Our previous studies have shown that this pattern does not relate to movement of free indium that might be released from cells after administration (Nieda et al, 2004). After $24 \mathrm{~h}$, almost all cells were located in the liver and spleen and virtually no activity remained in the lungs. Although the timing of cell migration varied slightly, this pattern was consistent for all patients. Predominant accumulation of radioactivity in the lung, liver and spleen was consistent with a previous observation investigating initial localisation of tumourspecific $\alpha \beta$ T cells (Meidenbauer et al, 2003) and there was no blood pooling (as indicated by the absence of significant radioactivity within the cardiac shadow), indicating egress of $\mathrm{V} \gamma 9 \mathrm{~V} \delta 2 \mathrm{~T}$ cells from the circulating blood pool. Repeat treatments with labelled $\mathrm{V} \gamma 9 \mathrm{~V} \delta 2 \mathrm{~T}$ cells gave the same pattern in all patients assessed more than once, including subjects $\mathrm{B} 1$ and $\mathrm{A} 2$ described below.

Assessment of the number of peripheral blood $\mathrm{V} \gamma 9 \mathrm{~V} \delta 2 \mathrm{~T}$ cells at multiple time points in the $48 \mathrm{~h}$ after $\mathrm{V} \gamma 9 \mathrm{~V} \delta 2 \mathrm{~T}$ cell infusion, mirroring the time points at which we evaluated $\mathrm{V} \gamma 9 \mathrm{~V} \delta 2 \mathrm{~T}$ cell by indium labelling, showed no substantial change in the number of peripheral blood $\mathrm{V} \gamma 9 \mathrm{~V} \delta 2 \mathrm{~T}$ cells compared with pre-infusion levels. These data are consistent with the nuclear medicine data indicating that few of the $\mathrm{V} \gamma 9 \mathrm{~V} \delta 2 \mathrm{~T}$ cells remain in the bloodstream.

In patient $\mathrm{B} 1$, who presented with an $84 \times 57 \times 75 \mathrm{~mm}^{3}$ metastatic mass on the left adrenal gland, a proportion of $\mathrm{In}^{111}$-labelled $\mathrm{V} \gamma 9 \mathrm{~V} \delta 2 \mathrm{~T}$ cells appear to have migrated to the tumour by $1 \mathrm{~h}$ after infusion. Maximal activity was seen in the tumour area at $4 \mathrm{~h}$ and tracer (and presumably intact cells) remained in the metastatic tumour site for the remainder of the $48 \mathrm{~h}$ observation period (Figure $4 \mathrm{~A}-\mathrm{C}$ ). Accumulation of labelled cells in the tumour followed a different time course to that in other organs (Figure 4D). In patient A2, who presented with $89 \mathrm{~mm}$ and $26 \mathrm{~mm}$ tumours in the left lung, accumulation of labelled cells at the $89 \mathrm{~mm}$ tumour site was also observed at $4 \mathrm{~h}$, but this activity was more subtle than for patient B1 (data not shown) suggesting lower numbers of cells within the tumour site.

\section{DISCUSSION}

The phase I trial described here indicates that combination therapy involving $\mathrm{V} \gamma 9 \mathrm{~V} \delta 2 \mathrm{~T}$ cells with zoledronate is feasible in patients with advanced solid tumours and is well tolerated. Our results highlight a number of practical issues that need addressing in future studies, including ways of increasing the proportion of patients who may benefit from this treatment, the need for more studies evaluating the destination of infused cells and the need to evaluate $\mathrm{V} \gamma 9 \mathrm{~V} \delta 2 \mathrm{~T}$ cells in combination with other therapies. Despite the technical demands of generating $\mathrm{V} \gamma 9 \mathrm{~V} \delta 2 \mathrm{~T}$ cells for adoptive therapy, adoptive therapy is ideal for evaluating combinations of $\mathrm{V} \gamma 9 \mathrm{~V} \delta 2 \mathrm{~T}$ cells with other therapeutic modalities 

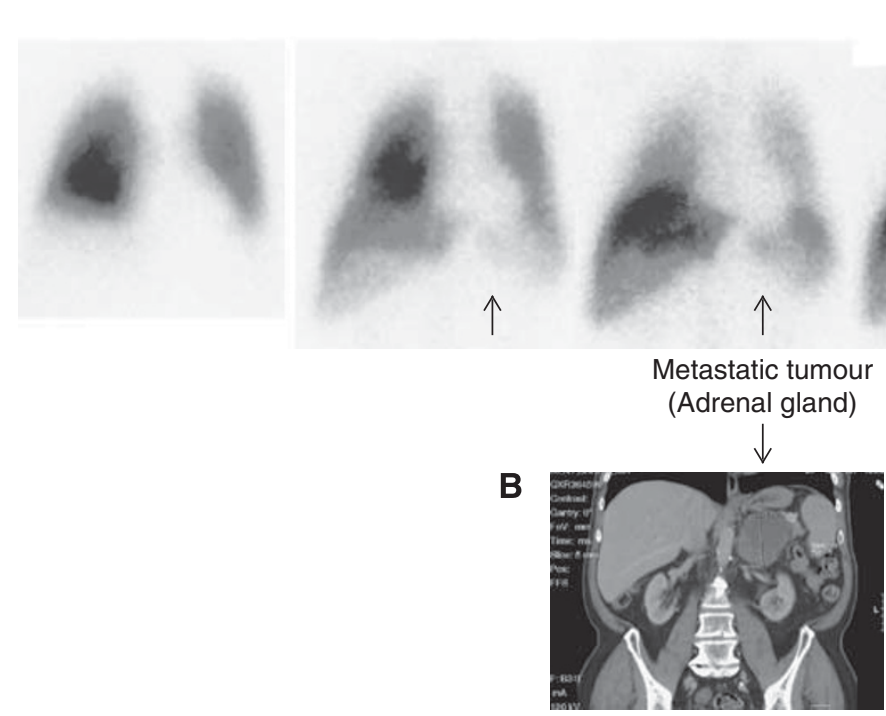

C

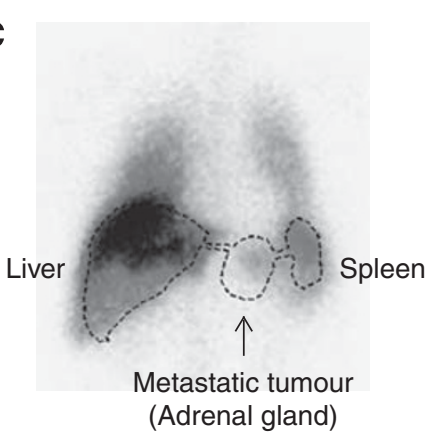

D
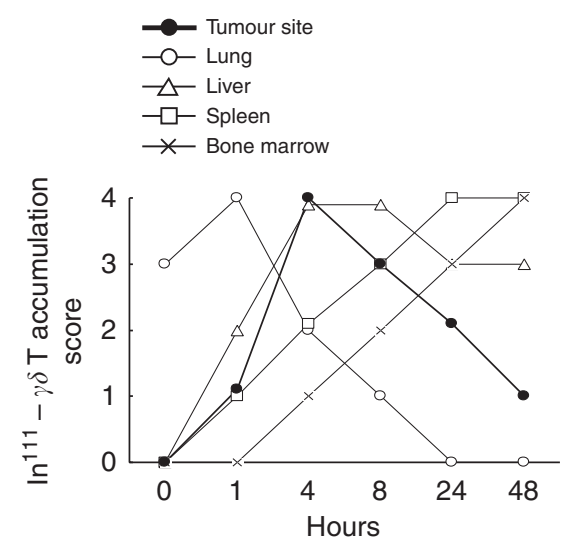

(Adrenal gland)

Figure 4 Localisation of adoptively transferred in vitro expanded $\vee \gamma 9 \vee \delta 2 T$ cells. (A) Anterior $\gamma$-camera images of the chest and abdomen at various time points after In 111 -labelled $\mathrm{V} \gamma 9 \mathrm{~V} \delta 2 \mathrm{~T}$ cell transfer $\left(5 \times 10^{7}\right.$ cells). Arrows point to location of tumour. (B and $\left.\mathbf{C}\right)$ Abdominal $C T$ scan $(\mathbf{B})$ showing the tumour mass, the outline of which is superimposed onto the $4 \mathrm{~h} \gamma$-image $(\mathbf{C})$ to show $\vee \gamma 9 \vee \delta 2 \mathrm{~T}$ cell activity at the tumour site. (D) Accumulation of $\vee \gamma 9 \vee \delta 2$ $T$ cells in different organs over time, scored on a scale of 0 to 4 , as described in the 'Materials and Methods' section $(\gamma \delta \mathrm{T}=\mathrm{\vee} \gamma \mathrm{V} \delta 2 \mathrm{~T}$ cells).

as administration of $\mathrm{V} \gamma 9 \mathrm{~V} \delta 2 \mathrm{~T}$ cells can be appropriately timed to ensure maximal synergy and avoidance of chemotherapeutic damage to $\mathrm{V} \gamma 9 \mathrm{~V} \delta 2 \mathrm{~T}$ cells.

Our study confirms that in vitro generation of $\mathrm{V} \gamma 9 \mathrm{~V} \delta 2 \mathrm{~T}$ cells for adoptive therapy is achievable in many cancer patients, despite advanced disease or previous chemotherapy. However, to maximise the potential for a therapeutic benefit from $\mathrm{V} \gamma 9 \mathrm{~V} \delta 2 \mathrm{~T}$ cell adoptive immune therapy higher cell doses may be required. Minimal therapeutic benefits were observed at the doses used in our study. To evaluate potential benefits of higher cell doses, factors inhibiting $\mathrm{V} \gamma 9 \mathrm{~V} \delta 2 \mathrm{~T}$ cell number and in vitro expansion capacity in cancer patients need to be addressed. Furthermore, ways to ensure $\mathrm{V} \gamma 9 \mathrm{~V} \delta 2 \mathrm{~T}$ cell survival (and possibly additional in vivo expansion), trafficking to tumour sites and retention of cytotoxic activity after infusion need to be explored.

In the initial stages of our study, depletion of circulating $\mathrm{V} \gamma 9 \mathrm{~V} \delta 2$ $\mathrm{T}$ cell numbers and in vitro expansion capacity were repeatedly observed after a single dose of zoledronate (data not shown). The changes were so marked that a protocol change was necessitated, avoiding zoledronate administration before cell harvesting. Similar aminobisphosphonate-induced decreases in $\mathrm{V} \gamma 9 \mathrm{~V} \delta 2 \mathrm{~T}$ cell numbers have been reported in patients with prostate cancer (Dieli et al, 2007) and in primates (Cendron et al, 2007). In our patient samples, low baseline percentages of $\mathrm{V} \gamma 9 \mathrm{~V} \delta 2 \mathrm{~T}$ cells and increased proportions of $\mathrm{Tn}+$ Temra subsets (as a fraction of total preculture $\mathrm{T}$ cells) predicted for low numbers of $\mathrm{V} \gamma 9 \mathrm{~V} \delta 2 \mathrm{~T}$ cells achieved after culture (data not shown).
Regulatory $\mathrm{T}$ cells may also negatively regulate $\mathrm{V} \gamma 9 \mathrm{~V} \delta 2 \mathrm{~T}$ cell proliferation. Regulatory T cells dampen T cell immunity (Zou, 2006) and are known to inhibit immune responsiveness in patients with advanced malignancy (Gallimore and Godkin, 2008). The percentage of Tregs in the blood of melanoma patients is significantly higher than that for healthy donors (Cesana et al, 2006), and we observed poor $\mathrm{V} \gamma 9 \mathrm{~V} \delta 2 \mathrm{~T}$ cell expansion in melanoma patients in our study. Our preliminary data (unpublished observations) and previous reports (Kabelitz et al, 2007; Kunzmann et al, 2009) indicate that depletion of Tregs from patient mononuclear cells leads to greater $\mathrm{V} \gamma 9 \mathrm{~V} \delta 2 \mathrm{~T}$ cell expansion in vitro.

Depletion of Tregs, either in vivo before harvest or in vitro and cryopreservation of large numbers of PBMCs before aminobisphosphonates, may be a pre-requisite for successful utilisation of $\mathrm{V} \gamma 9 \mathrm{~V} \delta 2 \mathrm{~T}$ cells for adoptive cell therapy in subjects who may receive aminobisphosphonates as part of their standard therapy for bone disease or as part of an immunotherapeutic strategy.

Efficient migration into tumour sites of actively cytotoxic subsets is a prerequisite for adoptively transferred $\mathrm{V} \gamma 9 \mathrm{~V} \delta 2 \mathrm{~T}$ cells to be therapeutically useful in cancer treatment. We demonstrated that $\mathrm{V} \gamma 9 \mathrm{~V} \delta 2 \mathrm{~T}$ cells we infused, which contained a range of subsets, had cytotoxic activity in vitro and included a substantial proportion of $\mathrm{V} \gamma 9 \mathrm{~V} \delta 2 \mathrm{~T}$ cells predicted to have cytotoxicity by virtue of CD56 expression (Thedrez et al, 2009; Urban et al, 2009). However, as we did not select subsets for our trafficking studies or our cytotoxicity assays, we do not know whether those cells eliciting in vitro cytotoxicity were those that migrated to the tumour sites. 
Increased effector memory $\gamma \delta \mathrm{T}$ cells are reported to correlate with objective clinical outcomes in patients treated with zoledronate and IL-2 (Dieli et al, 2007). The culture conditions we used generated large numbers of effector memory $\mathrm{V} \gamma 9 \mathrm{~V} \delta 2 \mathrm{~T}$ cells from the blood of cancer patients. In addition, as a surrogate assessment to predict the capacity for in vitro activated $\mathrm{V} \gamma 9 \mathrm{~V} \delta 2 \mathrm{~T}$ cells to migrate to tumour tissue, chemokine receptor expression was investigated. Expression of CCR5 and CXCR3 by effector T cells is reported to be important for trafficking to tumour sites as these receptors respond to a range of chemokines such as I-TAC, MIG, IP-10 (ligands for CXCR3) and RANTES, MIP- $1 \alpha$, MIP-1 $\beta$, MCP-2 (ligands for CCR5) released by tumours and inflammatory tissue (Moser and Loetscher, 2001). V $\gamma 9 \mathrm{~V} \delta 2 \mathrm{~T}$ cells from healthy donors are reported to express high constitutive levels of CCR5, but this is downregulated within $24-48 \mathrm{~h}$ of IPP stimulation in parallel with upregulation of the lymphoid-homing chemokine receptor, CCR7 (Glatzel et al, 2002; Brandes et al, 2003). Although a similar pattern of initial CCR5 downregulation and CCR7 upregulation was observed with our zoledronate- and IL-2-containing cultures (data not shown), after further $\mathrm{V} \gamma 9 \mathrm{~V} \delta 2 \mathrm{~T}$ cell expansion, there were large increases in both CCR5 and CXCR3 expression, peaking at days 7-10. Minimal changes in CCR7 and CXCR5 expression were observed, with levels remaining low at the end of the culture period.

The results of the trafficking studies with activated $\mathrm{V} \gamma 9 \mathrm{~V} \delta 2$ $\mathrm{T}$ cells reported here indicate localisation of $\mathrm{V} \gamma 9 \mathrm{~V} \delta 2 \mathrm{~T}$ cells at a large tumour site from as early as $1 \mathrm{~h}$ after infusion, with maximal activity at $4 \mathrm{~h}$ and persistence for at least $48 \mathrm{~h}$. Although only a minority of the administered cells localised to the tumour, this is the first direct demonstration of adoptively transferred $\mathrm{V} \gamma 9 \mathrm{~V} \delta 2$ $\mathrm{T}$ cell localisation at a tumour site with concurrent use of zoledronate. Although these results are encouraging, further work is required to characterise the properties of $\mathrm{V} \gamma 9 \mathrm{~V} \delta 2 \mathrm{~T}$ cells that migrate to the tumour and to increase the proportion of $\mathrm{V} \gamma 9 \mathrm{~V} \delta 2 \mathrm{~T}$ cells that migrate to tumour sites. The overall migration pattern we observed, in which initial, transient retention in the lungs is followed by movement predominantly to the liver and spleen, has been observed previously for other lymphocyte populations and is not specific to $\mathrm{V} \gamma 9 \mathrm{~V} \delta 2 \mathrm{~T}$ cells (Fisher et al, 1989; Nieda et al, 2004). It is unknown to what extent accumulation of activity in the lungs, liver and spleen indicates active homing of viable $\mathrm{V} \gamma 9 \mathrm{~V} \delta 2 \mathrm{~T}$ cells rather than passive 'trapping'. It is also unclear whether $\mathrm{V} \gamma 9 \mathrm{~V} \delta 2$ $\mathrm{T}$ cells infiltrate the parenchyma (providing an opportunity for therapeutic benefits for tumours in these organs) or remain within the lumen of blood vessels. More sensitive imaging technology is required to answer these questions.

\section{REFERENCES}

Abe Y, Muto M, Nieda M, Nakagawa Y, Nicol A, Kaneko T, Goto S, Yokogawa K, Suzuki K (2009) Clinical and immunological evaluation of zolendronate-activated Vgamma9Vdelta2 $\mathrm{T}$ cell-based immunotherapy for patients with multiple myeloma. Exp Hematol 37: 956-968

Bennouna J, Bompas E, Neidhardt EM, Rolland F, Philip I, Galea C, Salot S, Saiagh S, Audrain M, Rimbert M, Lafaye-de Micheaux S, Tiollier J, Negrier S (2008) Phase-I study of Innacell gammadelta, an autologous cell-therapy product highly enriched in gamma9delta $2 \mathrm{~T}$ lymphocytes, in combination with IL-2, in patients with metastatic renal cell carcinoma. Cancer Immunol Immunother 57: 1599- 1609

Bonneville M, Scotet E (2006) Human Vgamma9Vdelta2 T cells: promising new leads for immunotherapy of infections and tumours. Curr Opin Immunol 18: 539-546

Bouet-Toussaint F, Cabillac F, Toutirais O, Le Gallo M, Thomas de la Pintiere C, Daniel P, Genetet N, Meunier B, Dupont-Bierre E, Boudjema K, Catros V (2008) Vgamma9Vdelta2 T cell-mediated recognition of human solid tumors. Potential for immunotherapy of hepatocellular and colorectal carcinomas. Cancer Immunol Immunother 57: $531-539$
Evaluation of clinical responses was not a major end point of the trial but clearly no disease responses (other than stabilisation) were observed in the 15 patients treated with only the $\mathrm{V} \gamma 9 \mathrm{~V} \delta 2$ $\mathrm{T}$ cell/zoledronate combination. However, of potential interest, was the observation of clinical responses in three of three patients in whom conventional therapy was used in parallel with $\mathrm{V} \gamma 9 \mathrm{~V} \delta 2$ $\mathrm{T}$ cell/zoledronate therapy (one $\mathrm{CR}$ in combination with ongoing hormone therapy after failure of hormone therapy alone and two PR in combination with chemotherapy, including one patient with chemorefractory disease and another patient with very early relapse after previous chemotherapy). These clinical observations are consistent with in vitro studies indicating that the combination of $\mathrm{V} \gamma 9 \mathrm{~V} \delta 2 \mathrm{~T}$ cells with chemotherapy produces significantly greater tumour cell death than when either modality of treatment is used alone (Mattarollo et al, 2007). Of added interest are the previous in vitro observations of synergistic cytotoxic effects of CD16 expressing $\mathrm{V} \gamma 9 \mathrm{~V} \delta 2 \mathrm{~T}$ cells with therapeutic monoclonal antibodies (Tokuyama et al, 2008).

Previously, successful studies of adoptive immune therapy have included the use of IL-2 after cell therapy administration. The withdrawal of exposure to high concentrations of IL-2 used in the laboratory may limit the survival and function of $\mathrm{V} \gamma 9 \mathrm{~V} \delta 2 \mathrm{~T}$ cells after their infusion. We did not administer IL-2 to patients in our study to evaluate the toxicity profile of $\mathrm{V} \gamma 9 \mathrm{~V} \delta 2 \mathrm{~T}$ cells but this may have limited the potential for therapeutic benefits.

In summary, the combination of zoledronate and IL-2 generates large numbers of $\mathrm{V} \gamma 9 \mathrm{~V} \delta 2 \mathrm{~T}$ cells in vitro with cytotoxic activities against a range of tumour types, even in heavily pretreated patients with advanced malignancy. Administration of these cells is safe. Administered cells have a phenotype suggesting the potential to migrate to tumour tissues and we provide preliminary clinical evidence for migration of $\mathrm{V} \gamma 9 \mathrm{~V} \delta 2 \mathrm{~T}$ cells to tumour sites. As cells similar to those administered in this study have previously been shown to enhance the cytotoxic effects of chemotherapeutic agents and monoclonal antibodies, we propose further studies of zoledronate-activated $\mathrm{V} \gamma 9 \mathrm{~V} \delta 2 \mathrm{~T}$ cells in combination with chemotherapy and monoclonal antibodies.

\section{ACKNOWLEDGEMENTS}

This work was supported in part by the Gallipoli Medical Research Foundation and the Medinet Medical Institute. We thank Sue Douglas for her support with sample blood analyses, Dr Fuminori Moriyasu, Amanda Valuks and Sharon Senini for useful discussion, as well as the staff of the Clinical Nuclear Medicine Department at the Greenslopes Private Hospital for gamma camera scanning.
Braakman E, van de Winkel JG, van Krimpen BA, Jansze M, Bolhuis RL (1992) CD16 on human $\gamma \delta \mathrm{T}$ lymphocytes: expression, function, and specificity for mouse IgG isotypes. Cell Immunol 143: 97-107

Brandes M, Willimann K, Lang AB, Nam KH, Jin C, Brenner MB, Morita CT, Moser B (2003) Flexible migration program regulates gamma delta T-cell involvement in humoral immunity. Blood 102: 3693-3701

Carding SR, Egan PJ (2002) Gammadelta T cells: functional plasticity and heterogeneity. Nat Rev Immunol 2: 336-345

Cendron D, Ingoure S, Martino A, Casetti R, Horand F, Romagne F, Sicard H, Fournie JJ, Poccia F (2007) A tuberculosis vaccine based on phosphoantigens and fusion proteins induces distinct gammadelta and alphabeta T cell responses in primates. Eur J Immunol 37: 549-565

Cesana GC, DeRaffele G, Cohen S, Moroziewicz D, Mitcham J, Stoutenburg J, Cheung K, Hesdorffer C, Kim-Schulze S, Kaufman HL (2006) Characterization of $\mathrm{CD} 4+\mathrm{CD} 25+$ regulatory $\mathrm{T}$ cells in patients treated with high-dose interleukin-2 for metastatic melanoma or renal cell carcinoma. J Clin Oncol 24: 1169-1177

Chen ZW, Letvin NL (2003) Adaptive immune response of Vgamma2Vdelta2 T cells: a new paradigm. Trends Immunol 24: 213-219 
Clezardin P (2005) Anti-tumour activity of zoledronic acid. Cancer Treat Rev 31(Suppl 3): 1-8

Das H, Wang L, Kamath A, Bukowski JF (2001) Vgamma2Vdelta2 T-cell receptormediated recognition of aminobisphosphonates. Blood 98: 1616-1618

Dieli F, Vermijlen D, Fulfaro F, Caccamo N, Meraviglia S, Cicero G, Roberts A, Buccheri S, D'Asaro M, Gebbia N, Salerno A, Eberl M, Hayday AC (2007) Targeting human \{gamma\}delta\} $\mathrm{T}$ cells with zoledronate and interleukin-2. Cancer Res 67: 7450 - 7457

Ensslin AS, Formby B (1991) Comparison of cytolytic and proliferative activities of human gamma delta and alpha beta $\mathrm{T}$ cells from peripheral blood against various human tumor cell lines. J Natl Cancer Inst 83: 1564-1569

Fisher B, Packard BS, Read EJ, Carrasquillo JA, Carter CS, Topalian SL, Yang JC, Yolles P, Larson SM, Rosenberg SA (1989) Tumor localization of adoptively transferred indium-111 labelled tumor infiltrating lymphocytes in patients with metastatic melanoma. J Clin Oncol 7: 250-261

Gallimore A, Godkin A (2008) Regulatory T cells and tumour immunity observations in mice and men. Immunology 123: 157-163

Gertner-Dardenne J, Bonnafous C, Bezombes C, Capietto AH, Scaglione V, Ingoure S, Cendron D, Gross E, Lepage JF, Quillet-Mary A, Ysebaert L, Laurent G, Sicard H, Fournie JJ (2009) Bromohydrin pyrophosphate enhances antibody-dependent cell-mediated cytoxicity induced by therapeutic antibodies. Blood 113: 4875-4884

Giraudo E, Inoue M, Hanahan D (2004) An amino-bisphosphonate targets MMP-9-expressing macrophages and angiogenesis to impair cervical carcinogenesis. J Clin Invest 114: 623-633

Glatzel A, Wesch D, Schiemann F, Brandt E, Janssen O, Kabelitz D (2002) Patterns of chemokine receptor expression on peripheral blood gamma delta T lymphocytes: strong expression of CCR5 is a selective feature of $\mathrm{V}$ delta 2/V gamma 9 gamma delta $\mathrm{T}$ cells. J Immunol 168: 4920-4929

Gober HJ, Kistowska M, Angman L, Jeno P, Mori L, De Libero G (2003) Human $\mathrm{T}$ cell receptor gamma delta cells recognize endogenous mevalonate metabolites in tumor cells. J Exp Med 197: 163-168

Green AE, Lissina A, Hutchinson SL, Hewitt RE, Temple B, James D, Boulter JM, Price DA, Sewell AK (2004) Recognition of nonpeptide antigens by human $\mathrm{V}$ gamma $9 \mathrm{~V}$ delta $2 \mathrm{~T}$ cells requires contact with cells of human origin. Clin Exp Immunol 136: 472-482

Guo BL, Liu Z, Aldrich WA, Lopez RD (2005) Innate anti-breast cancer immunity of apoptosis-resistant human gammadelta-T cells. Breast Cancer Res Treat 93: 169-175

Kabelitz D, Wesch D, He W (2007) Perspectives of gammadelta T cells in tumor immunology. Cancer Res 67: 5-8

Kabelitz D, Wesch D, Pitters E, Zoller M (2004) Characterization of tumor reactivity of human $\mathrm{V}$ gamma $9 \mathrm{~V}$ delta 2 gamma delta $\mathrm{T}$ cells in vitro and in SCID mice in vivo. J Immunol 173: 6767-6776

Kato Y, Tanaka Y, Miyagawa F, Yamashita S, Minato N (2001) Targeting of tumor cells for human gamma delta $\mathrm{T}$ cells by nonpeptide antigens. J Immunol 167: 5092 - 5098

Knight LA, Conroy M, Fernando A, Polak M, Kurbacher CM, Cree IA (2005) Pilot studies of the effect of zoledronic acid (Zometa) on tumor-derived cells ex vivo in the ATP-based tumor chemosensitivity assay. Anticancer Drugs 16: $969-976$

Kobayashi H, Tanaka Y, Yagi J, Osaka Y, Nakazawa H, Uchiyama T, Minato N, Toma H (2007) Safety profile and anti-tumor effects of adoptive immunotherapy using gamma-delta $\mathrm{T}$ cells against advanced renal cell carcinoma: a pilot study. Cancer Immunol Immunother 56: 469-476

Kondo M, Sakuta K, Noguchi A, Ariyoshi N, Sato K, Sato S, Sao K, Hosoi A, Nakjima J, Yoshida Y, Shiraishi K, Nakagawa K, Kakimi K (2008) Zoledronate facilitates large-scale ex vivo expansion of functional $\gamma \delta$ $\mathrm{T}$ cells from cancer patients for use in adoptive immunotherapy. Cytotherapy 10: $842-856$

Kunzmann V, Kimmel B, Herrmann T, Einsele H, Wilhelm M (2009) Inhibition of phosphoantigen-mediated gammadelta T-cell proliferation by CD4+ CD25+ FoxP3+ regulatory T cells. Immunology 126: $256-267$

Lanier LL, Kipps TJ, Phillips JH (1985) Functional properties of a unique subset of cytotoxic CD3+ T lymphocytes that express Fc receptors for IgG (CD16/Leu-11 antigen). J Exp Med 162: 2089-2106

Liu Z, Guo BL, Gehrs BC, Nan L, Lopez RD (2005) Ex vivo expanded human Vgamma9Vdelta2+ gammadelta-T cells mediate innate antitumor activity against human prostate cancer cells in vitro. J Urol 173: $1552-1556$
Lopez RD, Xu S, Guo B, Negrin RS, Waller EK (2000) CD2-mediated IL-12-dependent signals render human gamma delta-T cells resistant to mitogen-induced apoptosis, permitting the large-scale ex vivo expansion of functionally distinct lymphocytes: implications for the development of adoptive immunotherapy strategies. Blood 96: 3827-3837

Marten A, von Lilienfeld-Toal M, Buchler MW, Schmidt J (2007) Zoledronic acid has direct antiproliferative and antimetastatic effect on pancreatic carcinoma cells and acts as an antigen for delta2 gamma/delta $\mathrm{T}$ cells. J Immunother 30: 370 - 377

Mattarollo SR, Kenna T, Nieda M, Nicol AJ (2007) Chemotherapy and zoledronate sensitize solid tumour cells to Vgamma9Vdelta2 $\mathrm{T}$ cell cytotoxicity. Cancer Immunol Immunother 56: 1285-1297

Meidenbauer N, Marienhagen J, Laumer M, Vogl S, Heymann J, Andreesen R, Mackensen A (2003) Survival and tumor localization of adoptively transferred Melan-A-specific T cells in melanoma patients. J Immunol 170: $2161-2169$

Moser B, Loetscher P (2001) Lymphocyte traffic control by chemokines. Nat Immunol 2: 123-128

Nieda M, Okai M, Tazbirkova A, Lin H, Yamaura A, Ide K, Abraham R, Juji T, Macfarlane DJ, Nicol AJ (2004) Therapeutic activation of Valpha24+Vbeta11+ NKT cells in human subjects results in highly coordinated secondary activation of acquired and innate immunity. Blood 103: 383-389

Noguchi A, Kaneko T, Kamigaki T, Fujimoto K, Ozawa M, Saito M, Ariyoshi N, Goto S (2011) Zoledronate-activated $\mathrm{V} \gamma 9 \gamma \delta$ T cell-based immunotherapy is feasible and restores the impairment of $\gamma \delta \mathrm{T}$ cells in patients with solid tumors. Cytotherapy 13: $92-97$

Santini D, Vincenzi B, Dicuonzo G, Avvisati G, Massacesi C, Battistoni F, Gavasci M, Rocci L, Tirindelli MC, Altomare V, Tocchini M, Bonsignori M, Tonini G (2003) Zoledronic acid induces significant and long-lasting modifications of circulating angiogenic factors in cancer patients. Clin Cancer Res 9: 2893-2897

Sato K, Kimura S, Segawa H, Yokota A, Matsumoto S, Kuroda J, Nogawa M, Yuasa T, Kiyono Y, Wada H, Maekawa T (2005) Cytotoxic effects of gamma delta $\mathrm{T}$ cells expanded ex vivo by a third generation bisphosphonate for cancer immunotherapy. Int J Cancer 116: 94-99

Senaratne SG, Pirianov G, Mansi JL, Arnett TR, Colston KW (2000) Bisphosphonates induce apoptosis in human breast cancer cell lines. $\mathrm{Br} \mathrm{J}$ Cancer 82: 1459- 1468

Tassone P, Forciniti S, Galea E, Morrone G, Turco MC, Martinelli V, Tagliaferri P, Venuta S (2000) Growth inhibition and synergistic induction of apoptosis by zoledronate and dexamethasone in human myeloma cell lines. Leukemia 14: $841-844$

Thedrez A, Harly C, Morice A, Salot S, Bonneville M, Scotet E (2009) IL-21mediated potentiation of antitumor cytolytic and proinflammatory responses of human $\mathrm{V} \gamma 9 \mathrm{~V} \delta 2 \mathrm{~T}$ cells for adoptive immunotherapy. J Immunol 182: $3423-3431$

Therasse P, Arbuck SG, Eisenhauer EA, Wanders J, Kaplan RS, Rubinstein L, Verweij J, Van Glabbeke M, van Oosterom AT, Christian MC, Gwyther SG (2000) New guidelines to evaluate the response to treatment in solid tumors. J Natl Cancer Inst 92: 205-216

Todaro M, D'Asaro M, Caccamo N, Iovino F, Francipane MG, Meraviglia S, Orlando V, La Mendola C, Gulotta G, Salerno A, Dieli F, Stassi G (2009) Efficient killing of human colon cancer stem cells by gamma delta $\mathrm{T}$ lymphocytes. J Immunol 182: 7287-7296

Tokuyama H, Hagi T, Mattarollo SR, Morley J, Wang Q, Fai-So H, Moriyasu F, Nieda M, Nicol AJ (2008) $\mathrm{V} \gamma 9 \mathrm{~V} \delta 2 \mathrm{~T}$ cell cytotoxicity against tumor cells is enhanced by monoclonal antibody drugs-rituximab and trastuzumab. Int J Cancer 122: 2526-2534

Urban EM, Li H, Armstrong C, Focaccetti C, Cairo C, Pauza CD (2009) Control of CD56 expression and tumor cell cytotoxicity in human Vgamma2Vdelta2 T cells. BMC Immunol 21: 10-50

Viey E, Fromont G, Escudier B, Morel Y, Da Rocha S, Chouaib S, Caignard A (2005) Phosphostim-activated gamma delta $\mathrm{T}$ cells kill autologous metastatic renal cell carcinoma. J Immunol 174: 1338-1347

Wilhelm M, Kunzmann V, Eckstein S, Reimer P, Weissinger F, Ruediger T, Tony HP (2003) Gammadelta T cells for immune therapy of patients with lymphoid malignancies. Blood 102: 200-206

Zou W (2006) Regulatory T cells, tumour immunity and immunotherapy. Nat Rev Immunol 6: 295-307

This work is published under the standard license to publish agreement. After 12 months the work will become freely available and the license terms will switch to a Creative Commons Attribution-NonCommercial-Share Alike 3.0 Unported License. 